\title{
Penelitian Administratif di Pengadilan Tata Usaha Negara
}

\author{
Adek Dwinanda Putri \\ Email: aleshaadwin17@gmail.com \\ No BP: 2010003600340 \\ Universitas Ekasakti
}

\section{A. PENDAHULUAN}

Negara Republik Indonesia adalah negara hukum sebagaimana yang tercantum dalam UUD NRI 1945, yang bertujuan menciptakan kesejahteraan umum dan keadilan sosial. Prinsip dasar dalam sebuah konsepsi negara hukum menetapkan bahwa setiap tindakan atau perbuatan pemerintah (bestuurshandelingen) haruslah berdasarkan pada peraturan perundang-undangan atau berdasarkan pada adanya suatu legitimasi atau kewenangan, sehingga tindakan atau perbuatan pemerintah tersebut dipandang absah adanya. Disamping itu, dalam negara hukum juga dianut prinsip bahwa setiap penggunaan kewenangan pemerintahan harus disertai dengan pertanggungjawaban hukum.

Dalam praktik, freies Ermessen ini membuka peluang terjadinya benturan kepentingan antara pemerintah dengan warga negara. Konsepsi negara hukum mengindikasikan ekuilibrium antara hak dan kewajiban. Salah satu sarana untuk menjaga ekuilibrium adalah melalui peradilan administrasi, sebagai peradilan khusus yang berwenang dan menyelesaikan sengketa antara pemerintah dengan warga Negara.

Adanya peradilan khusus tersebut pada konsep rechtsstaat menunjukkan adanya perlindungan hukum dan melindungi hak-hak warga negara. Dalam Pasal 24 ayat (1) UUD NRI 1945 tercantum bahwa Kekuasaan Kehakiman merupakan kekuasaan yang merdeka untuk menyelenggarakan peradilan guna menegakkan hukum dan keadilan. 
Selanjutnya dalam Pasal 24 ayat (2) dijelaskan Kekuasaan Kehakiman dilakukan oleh sebuah Mahkamah Agung dan badan peradilan yang berada di bawahnya dalam lingkungan peradilan umum, lingkungan peradilan agama, lingkungan peradilam militer, lingkungan peradilan tata usaha Negara oleh sebuah Makamah Konstitusi.

Pengadilan Tata Usaha Negara (PTUN) dibentuk dengan Keputusan Presiden (Keppres), dan sampai dengan sekarang ada 26 PTUN. PTUN mempunyai wewenang untuk memeriksa, memutus dan menyelesaikan sengketa tata usaha negara pada tingkat pertama.

Tujuan dibentuknya Peradilan Tata Usaha Negara adalah untuk memberikan perlindungan kepastian hukum, tidak hanya untuk rakyat semata-mata melainkan juga bagi pemerintah. Hal tersebut dilakukan dalam rangka menjaga dan memelihara keseimbangan antara kepentingan masyarakat dengan kepentingan individu demi terwujudnya pemerintahan yang kuat, bersih dan berwibawa dalam Negara hokum berdasarkan Pancasila.

Pengadilan Tata Usaha Negara (PTUN) merupakan salah satu pilar peradilan dari empat peradilan yang ada di lingkungan Mahkamah Agung. Pengadilan Tata Usaha Negara dibentuk berdasarkan Undang-Undang No. 5 Tahun 1986 Tentang Peradilan Tata Usaha Negara. Sampai saat ini UndangUndang No. 5 Tahun 1986 telah mengalami dua kali perubahan/revisi yaitu dengan Undang-Undang No. 9 Tahun 2004 dan UndangUndang No. 51 Tahun 2009. Pengadilan Tata Usaha Negara merupakan Pengadilan Administrasi yang mengkhususkan pengujiannya pada Keputusan Pejabat Tata Usaha Negara. Syarat Keputusan Pejabat Tata Usaha Negara yang dapat diuji oleh Pengadilan Tata Usaha Negara adalah Keputusan Pejabat Tata Usaha Negara yang memenuhi 
ketentuan Pasal 1 Angka 9 UU No. 51 Tahun 2009 yang menyebutkan bahwa "Keputusan Tata Usaha Negara adalah suatu penetapan tertulis yang dikeluarkan oleh badan atau Pejabat Tata Usaha Negara yang berisi Tindakan Hukum Tata Usaha Negara yang berdasarkan Peraturan Perundang-Undangan yang berlaku, yang bersifat konkret, individual, dan final, yang menimbulkan akibat hukum bagi seseorang atau badan hukum perdata". Apabila suatu Keputusan Pejabat Tata Usaha Negara telah memenuhi secara kumulatif ketentuan Pasal 1 Angka 9 UU No. 51 Tahun 2009, maka seseorang atau Badan Hukum Perdata yang merasa kepentingannya dirugikan oleh Keputusan Tata Usaha Negara dapat mengajukan gugatan kepada Badan atau Pejabat Tata Usaha Negara yang membuat Keputusan Tata Usaha Negara tersebut melalui Pengadilan Tata Usaha Negara. Pengajuan Gugatan melalui pengadilan Tata Usaha Negara dapat dilakukan langsung oleh orang atau badan hukum perdata yang bersangkutan atau dapat diwakili oleh kuasa hukum yang berprofesi sebagai Advokat. Setelah perkara masuk ke Pengadilan Tata Usaha Negara, maka mulai saat itu, tanggung jawab penyelesaian perkara tersebut berada di pundak Pengadilan. Pengadilan akan memeriksa dan memutus Perkara yang masuk ke PTUN dalam jangka waktu paling lama 6 bulan . Supaya gugatan yang disampaikan oleh Penggugat isinya sesuai dengan aturan yang berlaku di lingkungan Pengadilan Tata usaha Negara, ada baiknya calon penggugat terutama yang tidak menggunakan jasa Advokat untuk memahami gugatan ini secara terperinci.

Seseorang atau badan hukum perdata yang merasa kepentingannya dirugikan oleh Keputusan Tata Usaha Negara dapat mengajukan gugatan ke PTUN yang berwenang untuk mengadilinya.Penyelesaian sengketa di PTUN tahapannya yang pertama adalah penelitian administrasi. 


\section{B. PEMBAHASAN}

Penelitian Administrasi dilakukan oleh Kepaniteraan, merupakan tahap pertama untuk memeriksa gugatan yang masuk dan telah didaftar serta mendapat nomor register yaitu setelah Penggugat/ kuasanya menyelesaikan administrasinya dengan membayar uang panjar perkara. UU No. 5 Tahun 1986 jo UU No. 9 Tahun 2004 tidak menentukan secara tegas pengaturan tentang penelitian segi administrasi terhadap gugatan yang telah masuk dan didaftarkan dalam register perkara di Pengadilan, akan tetapi dari ketentuan Pasal 62 ayat (1) huruf b UU No. 5 Tahun 1986 jo UU No. 9 Tahun 2004 yang antara lain menyatakan :

"Syarat-syarat gugatan sebagaimana dimaksudkan dalam Pasal 56 tidak terpenuhi oleh penggugat sekalipun ia telah diberitahukan dan diperingatkan"

Apabila Objek dan Subjek gugatan telah terpenuhi dan masih dalam tenggang waktu yang ditentukan oleh Peraturan Perundang-undangan yang berlaku, maka gugatan dapat diajukan dengan syarat sebagai berikut :

a. Syarat formiil

$\checkmark$ Identitas para pihak: nama, kewarganegaraan, tempat tinggal dan pekerjaan penggugat atau kuasanya;

$\checkmark \quad$ Nama, jabatan dan tempat kedudukan Tergugat;

b. Syarat materiil

$\checkmark \quad$ Dasar gugatan (posita);

$\checkmark \quad$ Hal yang diminta untuk diputuskan oleh pengadilan (petitum). 
Dalam Surat Edaran MA No.2/1991 tentang Petunjuk Pelaksanaan Beberapa Ketentuan Dalam UU No. 5 Tahun1986 diatur mengenai Penelitian Administrasi :

1. Petugas yang berwenang untuk melakukan penelitian administrasi adalah Panitera, Wakil Panitera, Panitera Muda Perkara sesuai pembagian tugas yang diberikan.

2. Pada setiap surat gugatan yang masuk haruslah segera dibubuhi stempel dan tanggal pada sudut kiri atas halaman pertama yang menunjuk mengenai :

a. Diterimanya surat gugatan yang bersangkutan.

b. Setelah segala persyaratan dipenuhi dilakukan pendaftaran nomor perkaranya setelah membayar panjar biaya perkara.

c. Perbaikan formal surat gugatan (jika memang ada).

d. Surat gugatan tidak perlu dibubuhi materai tempel, karena hal tersebut tidak disyaratkan oleh UU.

e. Nomor Register perkara di PTTUN harus dipisahkan antara perkara tingkat banding dan perkara yang diajukan ke PTTUN sebagai instansi tingkat pertama (vide Pasal 51 ayat 3 UU No. 5 Tahun1986).

f. Di dalam kepala surat, alamat kantor PTUN atau PTTUN harus ditulis secara lengkap termasuk kode posnya walaupun mungkin kotanya berbeda. Misalnya :

Pengadilan Tata Usaha Negara Surabaya Jalan ... $\quad$ No...diSidoarjo Kode Pos ......(Tentang hal ini harus disesuaikan dengan penyebutan yang telah ditentukan dalam UU No. 19 Tahun1960, Keppres No. 52 tahun 1990). 
g. Identitas Penggugat harus dicantumkan secara lengkap dalam surat gugatan sebagaimana yang ditentukan dalam Pasal 56 UU No. 5 Tahun1986. Untuk memudahkan penanganan kasus-kasus dan demi keseragaman model surat gugatan harus disebutkan terlebih dahulu nama dari pihak Penggugat pribadi (in person) dan baru disebutkan nama kuasa yang mendampingi, sehingga dalam register perkara akan tampak jelas siapa pihak-pihak yang berperkara senyatanya. Serta Penelitian administratif supaya dilakukan secara formal tentang bentuk dan isi gugatan sesuai Pasal 56 dan tidak menyangkut segi materiil gugatan. Namun dalam tahap ini Panitera harus memberikan petunjuk-petunjuk seperlunya dan dapat meminta kepada pihak untuk memperbaiki yang dianggap perlu. Sekalipun demikian, Panitera tidak berhak menolak pendaftaran perkara tersebut dengan dalih apapun juga yang berkaitan dengan materi gugatan.

h. a. Pendaftaran perkara di tingkat pertama dan banding dimasukkan dalam register setelah yang bersangkutan membayar uang muka atau panjar biaya perkara yang ditaksir oleh panitera sesuai Pasal 59 sekurang-kurangnya sebesar Rp 50.000,00 (lima puluh ribu rupiah).

b. Dalam perkara yang diajukan melalui pos, panitera harus memberi tahu tentang pembayaran uang muka kepada penggugat dengan diberi waktu paling lama 6 (enam) bulan bagi Penggugat itu untuk memenuhi dan kemudian diterima di Kepaniteraan Pengadilan, terhitung sejak dikirimkannya surat pemberitahuan tersebut dan uang muka biaya perkara 
belum diterima di Kepaniteraan, maka perkara Penggugat tidak akan didaftar c. Walaupun gugatan yang dikirim melalui pos selama masih belum dipenuhi pembayaran uang muka biaya perkara dianggap sebagai surat biasa, akan tetapi kalau sudah jelas merupakan surat gugatan, maka harus tetap disimpan di Kepaniteraan Muda Bidang Perkara dan harus dicatat dalam Buku Bantu Register dengan mendasar pada tanggal diterimanya gugatan tersebut, agar dengan demikian ketentuan tenggang waktu dalam Pasal 55 tidak terlampaui.

i. Dalam hal Penggugat bertempat tinggal jauh dari PTUN dimana ia akan mendaftarkan gugatannya, maka tentang pembayaran uang muka biaya perkara dapat ditempuh dengan cara :

1. Panjar biaya perkara dapat dibayarkan melalui PTUN mana gugatan diajukan yang terdekat dengan tempat tinggalnya. Ongkos kirim ditanggung penggugat di luar panjar biaya perkara.

2. Panjar biaya perkara dikirim langsung kepada PTUN dimana ia mendaftarkan gugatannya.

j. a. Dalam hal suatu pihak didampingi kuasa, maka bentuk Surat Kuasa Khusus dengan materai secukupnya, dan Surat Kuasa Khusus yang diberi cap jempol haruslah dikuatkan (waarmerking) oleh pejabat yang berwenang.

b. Surat Kuasa Khusus bagi pengacara/advokat tidak perlu dilegalisir.

c. Dalam pemberian kuasa dibolehkan adanya substitusi tetapi dimungkinkan 
pula adanya kuasa insidentil.

d. Surat kuasa tidak perlu didaftarkan di Kepaniteraan PTUN.

k. Untuk memudahkan pemeriksaan perkara selanjutnya maka setelah suatu perkara didaftarkan dalam register dan memperoleh nomor perkara, oleh staf kepaniteraan dibuatkan resume gugatan terlebih dahulu sebelum diajukan kepada Ketua Pengadilan, dengan bentuk formal yang isinya pada pokoknya sebagai berikut :

1) Siapa subyek gugatan, dan apakah penggugat maju sendiri ataukah diwakili oleh Kuasa.

2) Apa yang menjadi obyek gugatan, dan apakah obyek gugatan tersebut termasuk dalam pengertian Keputusan TUN yang memenuhi unsur Pasal 1 angka 3 UU No. 5 Tahun 1986.

1. Apakah yang menjadi alasan-alasan gugatan, dan apakah alasan tersebut memenuhi unsur Pasal 53 ayat 2 huruf a, b, dan c UU No. 5 Tahun 1986. (Setelah keluarnya UU No. 9 Tahun 2004 alasan gugatan mendasarkan pada Pasal 53 ayat 2 huruf a dan b UU No. 9 Tahn 2004).

2. Apakah yang menjadi petitum atau isi gugatan, yaitu hanya pembatalan Keputusan TUN saja, ataukah ditambah pula dengan tuntutan ganti rugi dan/atau rehabilitasi. 
Untuk penelitian syarat-syarat formal gugatan, Panitera atau staf Kepaniteraan

dapat memberikan catatan atas gugatan tersebut, untuk disampaikan kepada Ketua Pengadilan untuk ditindaklanjuti dengan Prosedur Dismissal.

\section{PENUTUPAN}

Proses pemeriksaan administratif di pengadilan tata usaha negara :

1. Penelitian awal surat gugatan.

2. Pemberitahuan Nomor Rekening dan Besarnya Panjar Biaya Perkara kepada Calon Penggugat.

3. Penyerahan Bukti Pembayaran Panjar Biaya Meja I Perkara oleh Penggugat .

4. Pembuatan SKUM.

5. Pemberian Nomor Perkara

6. Pencatatan ke Buku Register Induk Perkara

7. Petugas Meja II menyerahkan Berkas ke Meja II Panmud Perkara.

8. Menerima dan mencatat Surat Kuasa dari Kuasa Hukum pihak yang bersengketa dalam buku bantu pendaftaran Surat Kuasa. 15 Menit Kepaniteraan Hukum.

9. Mengagendakan Surat Kuasa ke dalam Buku Register Pendaftaran Surat Kuasa.

10. Menarik PNBP dari legalisasi surat kuasa 15 menit Bendahara Penerima.

11. Panmud Perkara membuat Daftar Periksa (check list) kelengkapan berkas perkara dan Formulir Penetapan Majelis 30 menit Panmud Perkara

12. Panmud Perkara menyerahkan berkas perkara ke Wakil Panitera (Wapan.

13. Wapan menyerahkan berkas perkara ke Panitera 15 menit Wapan.

14. Panitera melakukan penelitian berkas perkara untuk diserahkan kepada KPTUN. 
15. Panitera menyerahkan berkas kepada KPTUN Panitera

\section{DAFTAR PUSTAKA}

Darmini Roza dan Laurensius Arliman S, Peran Pemerintah Daerah Di Dalam Melindungi Hak Anak Di Indonesia, Masalah-Masalah Hukum, Volume 47, Nomor 1, 2018. https://doi.org/10.14710/mmh.47.1.2018.10-21

Laurensius Arliman S, Peranan Metodologi Penelitian Hukum di Dalam Perkembangan Ilmu Hukum di Indonesia, Soumatera Law Review, Volume 1, Nomor 1, 201. http://doi.org/10.22216/soumlaw.v1i1.3346.

Laurensius Arliman S, Peran Badan Permusyawaratan Desa di Dalam Pembangunan Desa dan Pengawasan Keuangan Desa, Padjadjaran Journal of Law, Volume 4, Nomor 3, 2017. https://doi.org/10.15408/jch.v4i2.3433.

Laurensius Arliman S, Penanaman Modal Asing Di Sumatera Barat Berdasarkan Undang- Undang Nomor 25 Tahun 2007 Tentang Penanaman Modal, Supremasi Hukum, Volume 1, Nomor 1, 2018. http://dx.doi.org/10.36441/hukum.v1i01.102 .

Laurensius Arliman S, Memperkuat Kearifan Lokal Untuk Menangkal Intoleransi Umat Beragama Di Indonesia, Ensiklopedia of Journal, Volume 1, Nomor 1, 2018, https://doi.org/10.33559/eoj.v1i1.18.

Laurensius Arliman S, Perkawinan Antar Negara Di Indonesia Berdasarkan Hukum Perdata Internasional, Kertha Patrika, Volume 39, Nomor 3, 2017, https://doi.org/10.24843/KP.2017.v39.i03.p03.

Laurensius Arliman S, Partisipasi Masyarakat Di Dalam Pengelolaan Uang Desa Pasca Undang-Undang Nomor 6 Tahun 2014 Tentang Desa, Jurnal Arena Hukum, Volume 12, Nomor 2, 2019, https://doi.org/10.21776/ub.arenahukum.2019.01202.5.

Laurensius Arliman S, Mewujudkan Penegakan Hukum Yang Baik Di Negara Hukum Indonesia, Dialogica Jurnalica, Volume 11, Nomor 1, 2019, https://doi.org/10.28932/di.v11i1.1831.

Laurensius Arliman S, Mediasi Melalui Pendekatan Mufakat Sebagai Lembaga Alternatif Penyelesaian Sengketa Untuk Mendukung Pembangunan Ekonomi Nasional, UIR Law Review, Volume 2, Nomor 2, 2018, https://doi.org/10.25299/uirlrev.2018.vol2(02).1587

Laurensius Arliman S, Peranan Filsafat Hukum Dalam Perlindungan Hak Anak Yang Berkelanjutan Sebagai Bagian Dari Hak Asasi Manusia, Doctrinal, Volume 1, Nomor 2,2016.

Laurensius Arliman S, Ni Putu Eka Dewi, Protection of Children and Women's Rights in Indonesia through International Regulation Ratification, Journal of Innovation, Creativity and Change Volume 15, Nomor 6, 2021.

Laurensius Arliman S, Gagalnya Perlindungan Anak Sebagai Salah Satu Bagian Dari Hak Asasi Manusia Oleh Orang Tua Ditinjau Dari Mazhab Utilitarianisme, Jurnal Yuridis, Volume 3, Nomor 2, 2016, http://dx.doi.org/10.35586/.v3i2.180. 
Laurensius Arliman S, Tantangan Pendidikan Kewarganegaraan Pada Revolusi 4.0, Jurnal Ensiklopedia Sosial Review, Volume 2, Nomor 3, $2020 .$. 